\title{
The chert workshop of Tozal de la Mesa (Alins del Monte, Huesca, Spain) and its exploitation in historical times
}

\author{
Marta Sánchez de la Torre ${ }^{1}$, Luis Miguel García-Simón ${ }^{2}$, Rafael Domingo ${ }^{2}$, \\ Lourdes Montes ${ }^{2}$, Xavier Mangado ${ }^{1}$ \\ 1. SERP. University of Barcelona. 6-8 Montalegre St. 08001, Barcelona, Spain. \\ Email: Sánchez de la Torre: martasanchezdelatorre@ub.edu; Mangado:mangado@ub.edu \\ 2. PPVE. University of Zaragoza. Constitución Sq. 22001, Huesca, Spain. \\ Email: García-Simón: luisgarciasimon@gmail.com; Domingo: rdomingo@unizar.es; \\ Montes: lmontes@unizar.es
}

\begin{abstract}
:
In 2012, during a field survey to locate primary outcrops of cherts in the Carrodilla Mountain Range (Huesca, Spain), abundant remains of chert-knapping were found next to nodular cherts in primary and sub-primary position from the Garumnian limestones. Chert knapping evidences were discovered in Tozal de la Mesa mount, near the town of Alins del Monte (Huesca, Spain), in the first prepyrenean foothills of the province of Huesca.

In order to define the features of the workshop and to determine their limits, in 2015 we conducted a field survey. Due to these works, it has been possible to define the perimeter of the chert workshop as well as to collect abundant lithic remains of chert and other rocks (e.g., ophites) that may have been directly related to chert exploitation.

In this paper we are going to present the results obtained after the textural, micropaleontological, petrographic and mineralogical characterization of these cherts as well as the results of the technotypological and traceological analyses. Moreover, we will define the features of the chert workshop and its functionality.

The first approach to contextualize the recovered materials of Tozal de la Mesa workshop area has allowed determining an exploitation of the Garumnian cherts that has lasted until the late nineteenth century according to some recovered products (e.g., pottery) and to oral sources.
\end{abstract}

Keywords: Tremp formation; raw material exploitation; NE Iberia; Carrodilla Mountain Range; lithic procurement

\section{Introduction}

Chert was one of the most used stones for making lithic tools since Prehistory due to its concoidal fracture and mechanic characteristics: homogeneity and isotropy, tenacity, elasticity and hardness (Tarriño 2006).

Published by the School of History, Classics and Archaeology, University of Edinburgh ISSN: 2055-0472. URL: http://journals.ed.ac.uk/lithicstudies/

This work is licensed under a Creative Commons Attribution 2.5 UK: Scotland License. 
In the last two decades, studies based on the early stages of the Chaîne Opératoire Lithique (procurement and management of lithic raw materials) have increased, with important examples concerning the NE Iberia (Mangado 2005; Terradas 1996).

Nevertheless, and otherwise not surprisingly, these analyses have mainly focused on studies concerning prehistoric periods, where chert remains are abundant in the archaeological record.

However, rather than in small proportions, chert knapping continued during historical times with several applications. The most distinguished uses were agricultural, construction, to achieve fire or in relation with military armaments (Gibaja \& Palomo 2006). The last evidences of traditional chert knapping in NE Iberia are related to making threshing stones, activity in use until the mid-twentieth century in certain areas of the NE Iberian Peninsula.

In recent years, and specifically from the University of Granada, several studies based on the historical exploitation of chert in Andalusia have been developed. These studies have redefined chert workshops that previously had been characterised as prehistoric places and were, in fact, archaeological evidences of the historic use of chert (Roncal et al. 1996; Morgado \& Roncal 2009).

Thus, studies dedicated to chert knapping during historical times in the Middle Ebro valley, our study region, are reduced to some analyses of gunflints workshops in the Huerva valley (Barandiarán 1974; Pérez et al. 2010). These gunflint workshops are located near many hills and slops were outcrops of Miocene nodular cherts are abundant and possessing a high knapping aptitude. These workshops possess high amount of waste flakes and discoidal cores with recent fracture appearance. Occasionally some gunflints appear as part of the entire set (Pérez et al. 2010: 312).

In this paper we would like to present the chert workshop of Tozal de la Mesa as an example of the historical exploitation of chert in NE Iberia no related with a gunflint workshop.

\section{Workshop location and characteristics}

Our research area is located in Western Europe, specifically in the northeast of the Iberian Peninsula. This place presents a large mosaic of different geological and ecological environments, associated with the existence of three major geographical units: the Pyrenees, the Central Depression and the Mediterranean system.

The chert workshop of Tozal de la Mesa is located in the contact zone between the Pyrenees and the Central Depression, in an area known as the Carrodilla Mountain Range, being part of the Pyrenees foothills (Figure $1-\mathrm{C}$ ). These Pyrenean foothills are crossed from north to south by a large river basin that collects water from the Pyrenees and distributes it to the Mediterranean Sea via the Central Depression. The Cinca River is one of those axes which, in the Central Pyrenees, flow into the Ebro River basin, passing at few kilometres west of the Tozal de la Mesa workshop.

Chert knapping evidences were discovered near the town of Alins del Monte (Huesca, Spain) in the mount of Tozal de la Mesa, being part of the Carrodilla Mountain Range (Figure $1-\mathrm{E}$ ). This mountain presents a step relief with elevations that exceed $1000 \mathrm{~m}$ above sea level. The formation of this mountain range dates back to the late Cretaceous, when the Iberian and Eurasian shelves collided. This collision caused the compression and elevation of the huge amounts of sediments that had been deposited in the Pyrenees. As a result, the current reliefs of the Pyrenees rose.

The chert workshop was discovered in 2012, during a field survey to locate primary outcrops of cherts in the Carrodilla Mountain Range (Huesca, Spain). During these works abundant remains of chert-knapping were found next to nodular cherts outcropping in the 
Garumnian limestones in primary and sub-primary position. Chert remains were found next to a sandstone fluvial paleochannel with garumnian mudstones from a flood plain. Chert nodules originated some meters above, in the micritic limestones from the Garumnian (Figure 1 - D).
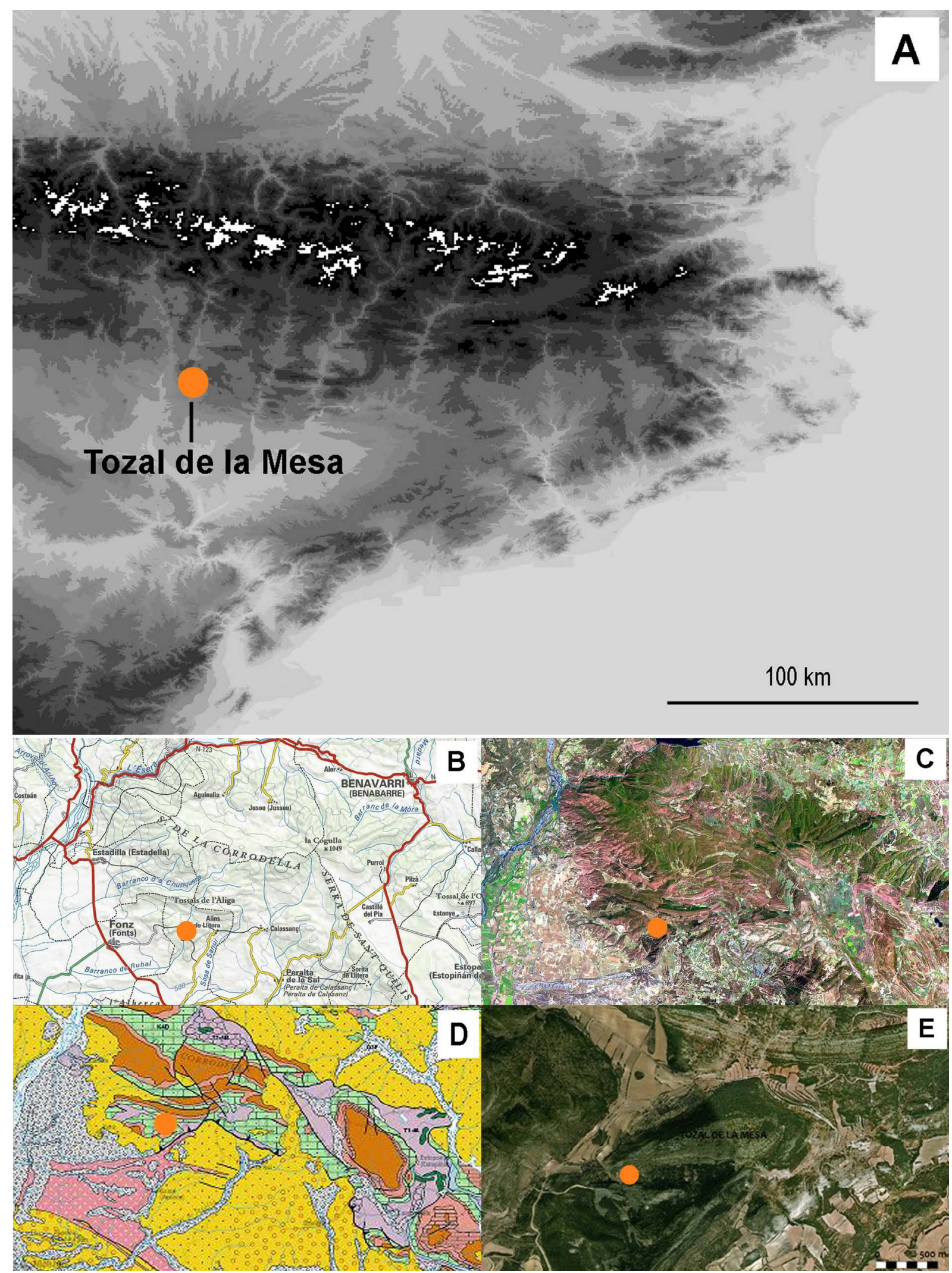

Figure 1. Geographical location of the chert workshop of Tozal de la Mesa. B) Topographical view; C and E) Geomorphological view; D) Geological view. 
In order to define the features of the workshop and to determine their limits, from May $18^{\text {th }}$ to May $20^{\text {th }} 2015$ a field survey was conducted, directed by three of us (R. Domingo, M. Sánchez de la Torre \& L.M. García-Simón.). This survey was authorized by the General Direction of the Cultural Heritage of the Aragon Government in Zaragoza on March $10^{\text {th }} 2015$ (file number: 049/2015).

During these works a systematic survey of the site was carried out. This survey included the collection of lithic remains as well as other elements that may have been directly related to a chert extraction activity in the place.

Due to these works, it has been possible to define the perimeter of the chert workshop as well as to collect abundant chert lithic remains and other rocks (e.g., ophites) that may have been directly related to chert exploitation.

With the use of a portable laptop connected to the satellite GPS network it was possible to establish accurately the position as well as the perimeter of the chert workshop. As a result, we detected a chert workshop area of about $5000 \mathrm{~m}^{2}$ and 10 special places were georeferred for presenting special features. Thus, we have defined:

A. Places with chert outcropping in subprimary position with some chert knapping evidences

B. Places with abundant lithic remains with no other archaeological remains

C. Places with some lithic remains in association with other archaeological materials (e.g., pottery) (Figure 2).
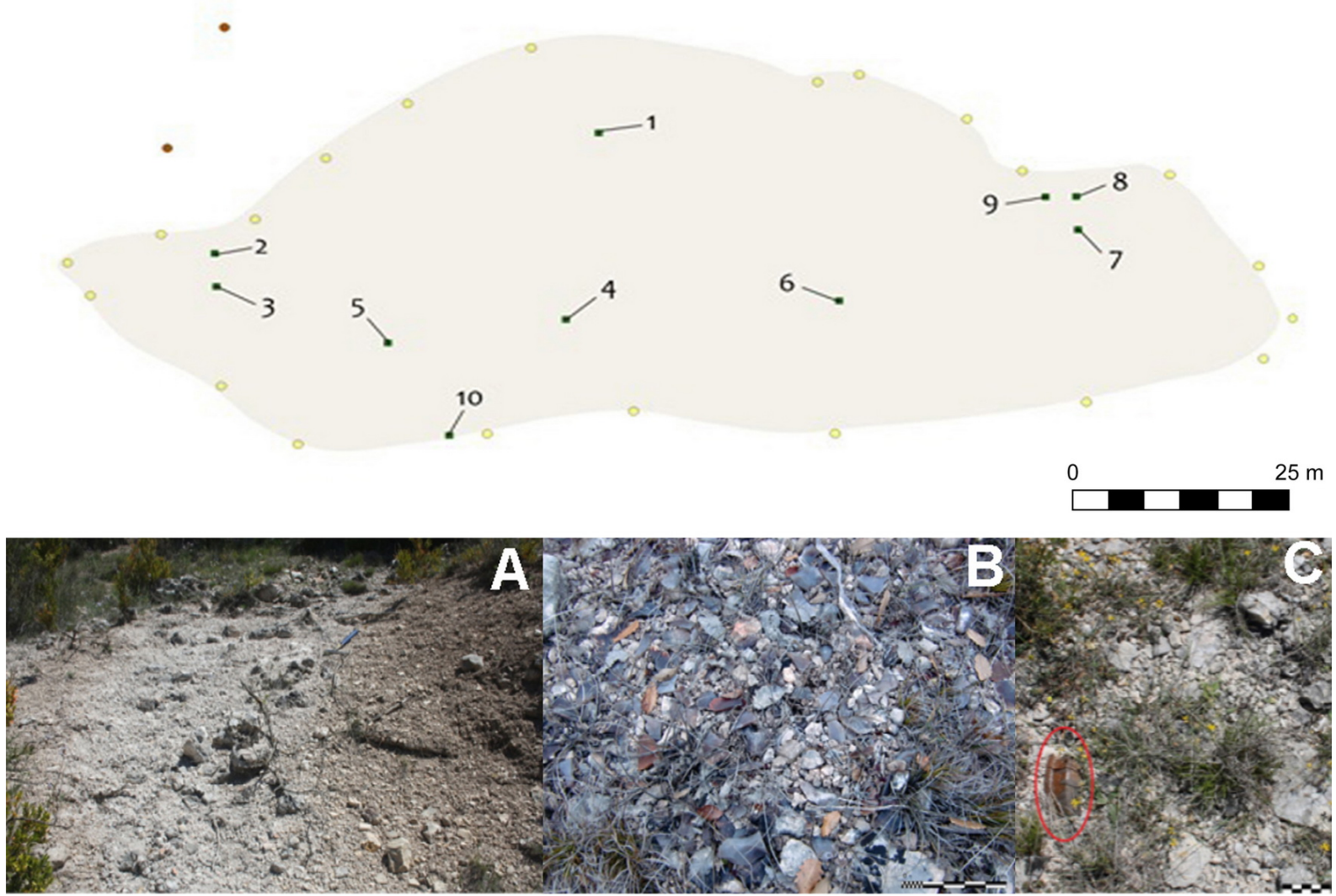

Figure 2. Georeferrenced places with some examples of the three types of places defined during the survey.

In Figure 2 the perimeter of the workshop can be observed in yellow circles, as well as the points of interest (red squares). Three points in orange colour appear outside the limits of the workshop. There were found one or at most two lithic evidences. Due to the low percentage value of these orange points we have not considered them in this study. 


\section{Methods}

The survey in the Tozal de la Mesa area consisted in an intensive archaeological survey of the delimited area. These works also contemplated the collection of lithic remains and other tools that may have been related with an extractive activity in the place. We registered the position of the workshop as well as all the recovered materials with a portable laptop connected to the GPS network. These works allowed us to capture the location and disposition of the remains in a topographic map of the area, which has been presented previously.

The recovered material was then analysed by archaeopetrological, techno-typological and use-wear methods in the laboratories of the University of Barcelona and the University of Zaragoza. The goal was to establish an archaeopetrological characterization of recovered chert remains, a typo-technological study and to determine possible use-wear evidences.

To accomplish the research objectives, we conducted an archaeopetrological study of the lithic samples recovered in the Tozal de la Mesa area. The characterization was done in terms of three scales of analyses, including a macroscopic, petrographic and mineralogical approach. First, a macroscopic examination was carried out using a binocular microscope, an Olympus SZ61 model (from 6.7 to $45 \mathrm{x}$ magnification) and a supplementary light source, depending on the samples (Cold Light transmitted Olympus TH4-200 model). Snapshots were taken with a coupled Olympus SC30 model camera.

Afterwards, a petrographic and micropaleontological characterization of some lithic samples was performed by analysing these cherts in thin sections, with thicknesses between 25 and $30 \mu \mathrm{m}$, that were created at the Servei de Làmina Prima laboratory of the University of Barcelona, and were analysed using a petrographic Olympus BX41 model microscope (from 40 to $400 \mathrm{x}$ magnification).

Finally, in order to find out the mineralogical composition, we analysed a sample by Xray diffraction (XRD) at the laboratories of the National Research Centre for Human Evolution (CENIEH) in Burgos.

\section{Results}

During the field Works up to 158 archaeological remains were collected. Of these, 148 were chert lithic remains, all of them with identical archaeopetrological characteristics as the Garumnian nodular cherts outcropping next to the workshop limits.

The suitability of these nodular cherts for knapping varies depending on the individual nodule. Macroscopically, these cherts present metal oxides and lenticular gypsum pseudomorph inclusions (Figure $3-\mathrm{A}$ ). No bioclastic elements have been identified. In some cases, there are cracks, often filled by macroquartz crystals. By petrographic microscope, a micro-criptoquartz mosaic fabric was the main texture (76\%). Other silica forms were present filling old pores: length-slow chalcedony (8\%), length-fast chalcedony (4\%) and macroquartz (8\%) (Figure $3-\mathrm{B}$ ). Non-silica components were scarce, only micritic residues (4\%) were observed.

The X- Ray Diffraction analysis has shown two major mineral phases: quartz and muscovite. A semi-quantitative analysis has been done following the Chung method (Chung 1974). As a result, in the sample analyzed quartz is represented with $89.9 \%$ and muscovite with $10.1 \%$ (Figure $3-\mathrm{C}$ ).

Concerning technological aspects, the $53 \%$ of the chert lithic industry does not possess cortical surfaces. The remaining $47 \%$ possesses marginal cortical surfaces $(9 \%)$, medium cortical surfaces $(16 \%)$ or total cortical surfaces $(6 \%)$ (Table 1$)$. When present, the cortex is primary-type, with scarce bearing and sandstone lithology, being diffused the contact between the siliceous mass and the cortex. 

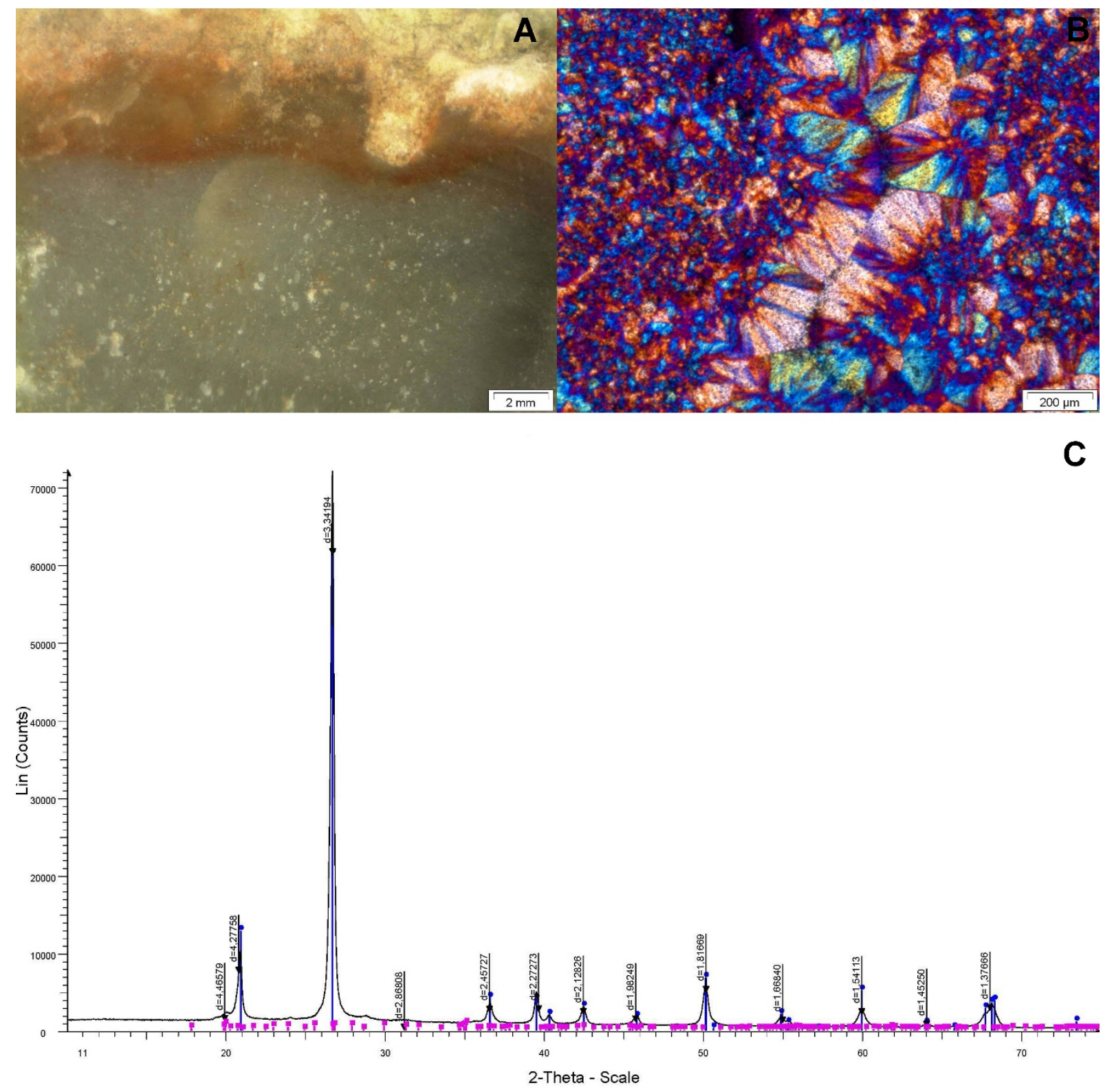

Figure 3. Garumnian cherts characteristics. A) Macroscopic view. B) Microscopic view. C) X-Ray diffractogram. Blue line: quartz (89,9\%); Pink line: muscovite $(10,1 \%)$.

Table 1. Presence of cortex in chert materials.

\begin{tabular}{|l|c|}
\hline CORTEX $\%$ & N. PIECES \\
\hline $0 \%$ cortex surfaces & 79 \\
\hline $25 \%$ cortex surfaces & 13 \\
\hline $50 \%$ cortex surfaces & 24 \\
\hline $75 \%$ cortex surfaces & 24 \\
\hline $100 \%$ cortex surfaces & 8 \\
\hline
\end{tabular}

The classification of the lithic archaeological assemblage according to the support shows 2 chert nodules, 5 cores ( 2 of them of unipolar debitage and the remaining 3 of multiple debitage), 115 knapping products and 26 debris (Table 2). The knapping products, therefore, play an important role in the archaeological set, showing the existence of a knapping activity of the nodular cherts outcropping in the Tozal de la Mesa area. 
Table 2. Chert materials distribution depending on the support.

\begin{tabular}{|l|c|}
\hline SUPPORT & N. PIECES \\
\hline Chert nodule & 2 \\
\hline Core & 5 \\
\hline Flake or fragmented flake & 84 \\
\hline Fragment of flake & 18 \\
\hline Blade or fragmented blade & 11 \\
\hline Fragment of blade & 2 \\
\hline Fragment & 26 \\
\hline
\end{tabular}

The macroscopic analysis of blades and flakes with a binocular microscope shows that the $30 \%$ of the debitage products with preserved bulk have been obtained by the direct percussion technique with metallic hard hammer. This technique is characterized for obtaining debitage products with wide and thick plain butts. The impact point is well delimited and usually is enclosed by a double fissure caused for the hammer. In addition, metal oxides traces are preserved, being another evidence of the use of metallic hard hammer (Figure 4).
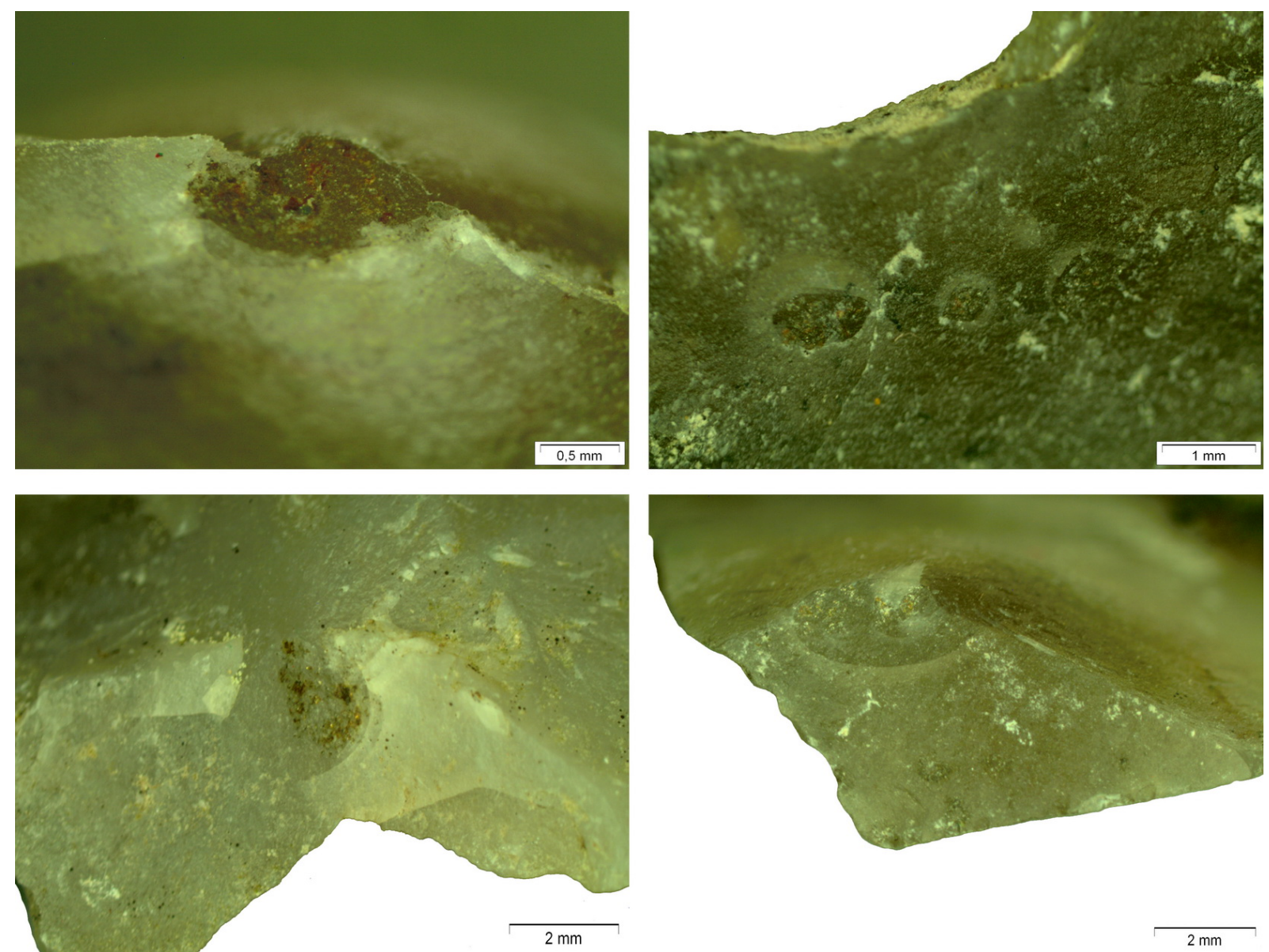

Figure 4. Flakes and blades butts with metal oxides and fissures caused by the use of a metallic hard hammer. (Scale bars: Top left - $0.5 \mathrm{~mm}$; top right - $1 \mathrm{~mm}$; bottom left - $2 \mathrm{~mm}$; bottom right - $2 \mathrm{~mm}$.)

In association with the presented chert remains were found 5 pieces made in ophite. In all cases they are fragmented or complete pebbles with one or two flatten bases, blow marks and subtriangular or rectangular sections. By possessing the features exposed they could be remains of maces or crushes (Figure 5). 


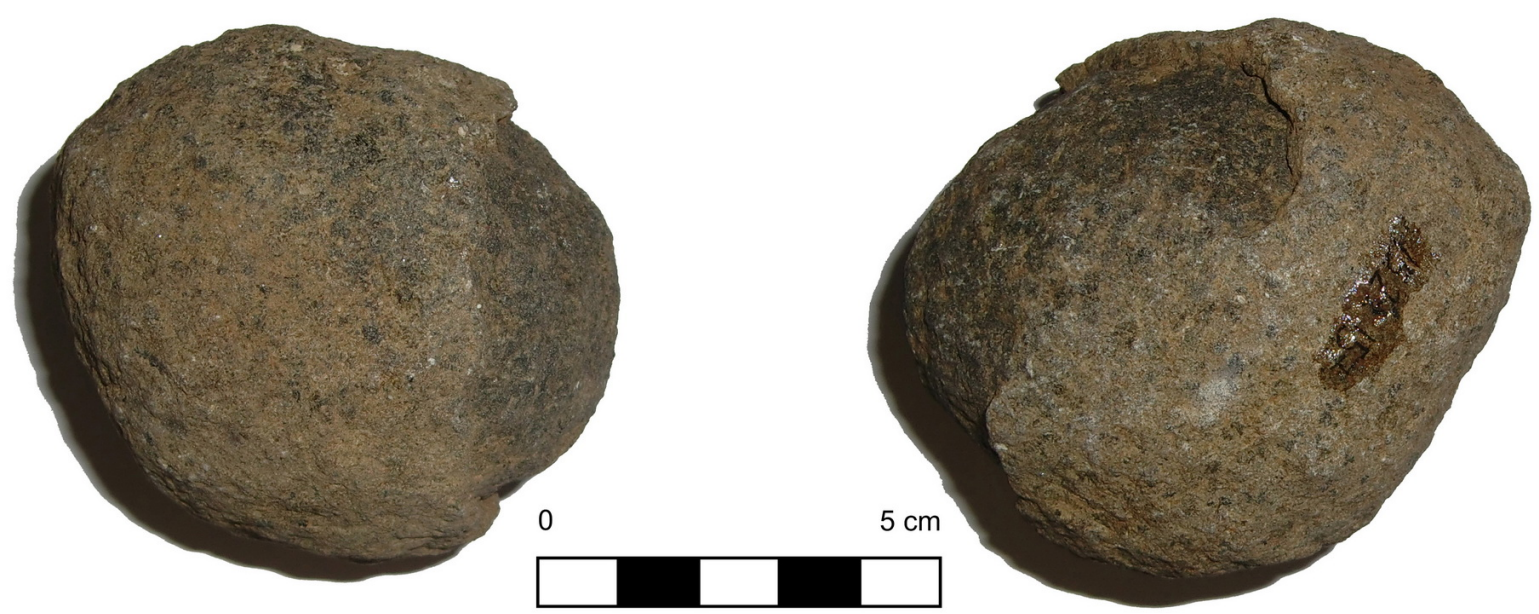

Figure 5. Pebble in ophite with blow marks found during the archaeological survey at Tozal de la Mesa area.

The remaining five elements of the archaeological set recovered during the field work are pottery elements. There are three fragments without form and two form elements. These are a handle and an edge with base. In all cases is wheel-made glazed pottery, probably made during the $19^{\text {th }}$ or $20^{\text {th }}$ century (Figure 6).

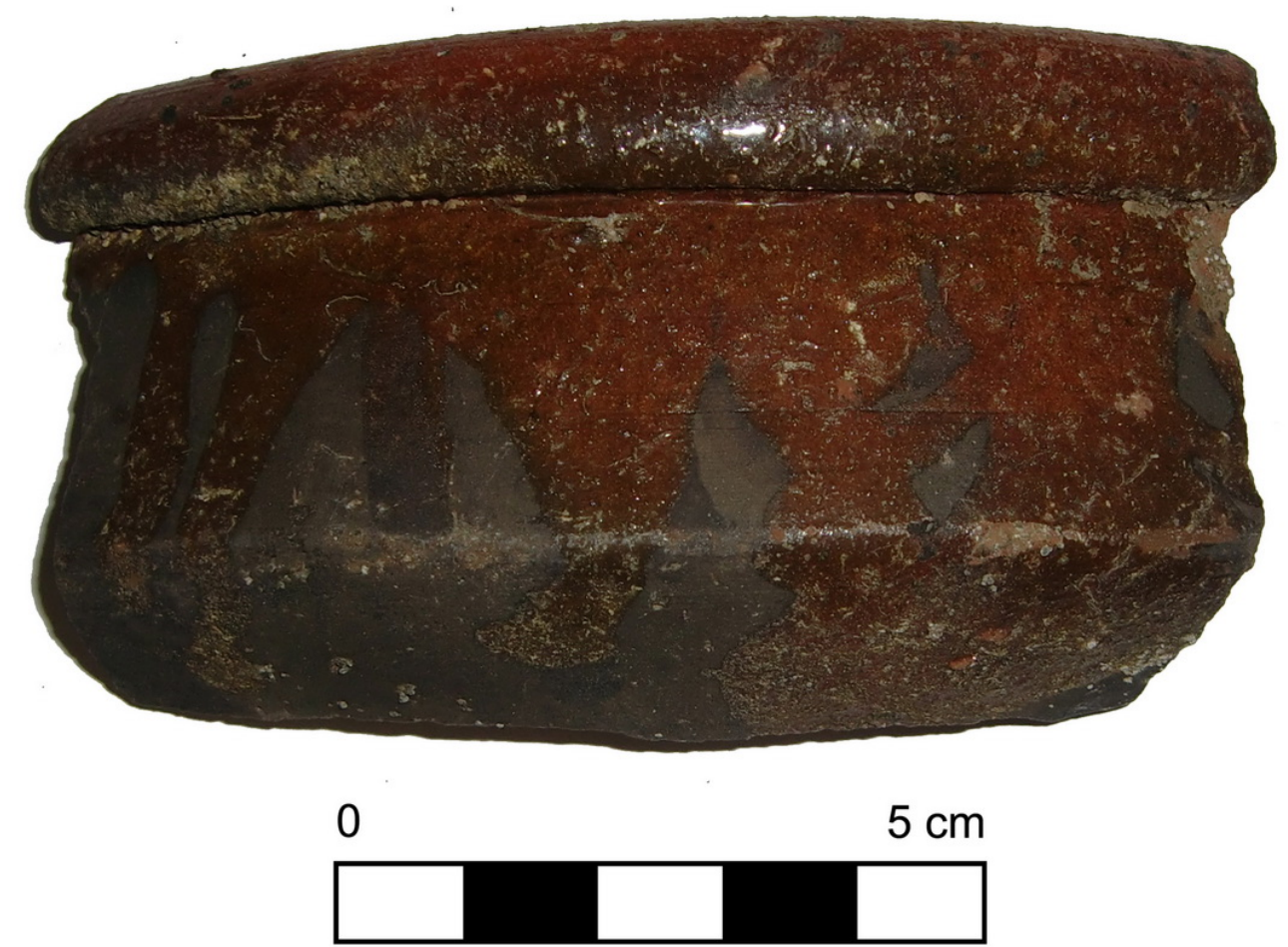

Figure 6. An edge with base wheel-made glazed pottery found during the archaeological survey at Tozal de la Mesa area.

\section{Discussion and conclusions}

This first approach to the recovered materials of Tozal de la Mesa workshop area has allowed us to determine the exploitation of the Garumnian chert nodules outcropping in the Carrodilla Mountain Range during historical times, as it has been observed in the recovered materials (evidences of a direct percussion with metallic hammer observed in the debitage 
products joined to the recovered pottery of the $19^{\text {th }}$ century). This chert workshop has lasted until the late nineteenth century, according to oral sources.

Concerning the workshop's functionality, the amount of recovered remains, as well as their characteristics, leads us thinking that we are not in front of a gunflint workshop. Firstly, the garumnian-exploited cherts possess cracks being their knapping aptitude medium. Moreover, the archaeological record does not reveal a debitage oriented towards the extraction of standardized supports for making gunflints. In only one case a flake presenting an approach to the desired morphologies has been observed. But this is only an approach and in any case is a finished tool or defines the characteristics of the archaeological set.

Thus, we believe that probably we are in front of a threshing chert workshop, activity in survival until the twentieth century in some places of the Iberian Peninsula. In these threshing boards, chert was inserted into a wooden board in order to separate the grain from the ears once picked up the cereal. To make these tools pieces with similar morphologies standardization would be necessary, but in any case a high standardization as the needed to elaborate gunflints would be required.

Nevertheless, although most of the recovered set presents characteristics that may well be attributed to an historical chert knapping maybe related with the manufacture of threshing pieces, we have found some special cases. There are several pieces that possess deep patina and different morphologies that could evidence a prehistoric exploitation of the workshop area. In this sense, the ophite industry could reaffirm this hypothesis.

However, being a survey that only involves the recovery of surface materials, it is assumed that if a prehistoric workshop had existed, it could be today underground.

Therefore, future work in the place will help without doubt to delve into the possible use of the Tozal de la Mesa chert workshop also during prehistoric times.

\section{Acknowledgements}

The research presented in this paper has been supported by an FPU grant from the Spanish Government that was held by one of us (M. Sánchez de la Torre) and the projects HAR 2011-26193 from the Spanish Government, and SGR 2014-108 from the Catalonia Government, both directed by Professor J.M. Fullola. This research was also supported by Prehistopyr (2010CTP-00008) and Palmesopyr (2012CTP-00008) research networks funded by the CTP.

This research is also supported by the Research Group PPVE - H07, funded by the Government of Aragón, and the projects HAR 2011-27197 and HAR 2014-59042P, all of them directed by Professor P. Utrilla. R. Domingo is a Ramón y Cajal researcher (RyC201312613).

\section{References}

Alonso, M. 2008, Estudo traceológico de instrumentos líticos do Brasil Central. Mestrado thesis at the Faculdade de Filosofia e Ciências Humanas, Programa de Pós-Graduação em Antropologia, Universidade Federal de Minas Gerais, Belo Horizonte, 102 p. (in Portuguese) (“Traceological study of lithic instruments of Central Brazil”)

Araujo, A.G.M. 2015, On Vastness and Variability: Cultural Transmission, Historicity, and the Paleoindian Record in Eastern South America. Anais da Academia Brasileira de Ciências, 87(2): 1239-1258. doi:10.1590/0001-3765201520140219 
Gibaja, J.F. \& Palomo, A. 2006, Pervivencias del uso del sílex en época moderna y contemporánea. Revista de Arqueología del siglo XXI, 297: 34-41. (in Spanish) ("Flint use survival during modern and contemporary times”)

Maluquer de Motes, J. 1955, Los talleres de sílex al aire libre del norte de Aragón. Príncipe de Viana, 58: 9-32. (in Spanish) ("The open-air flint workshops f northern Aragon”) URL: https://dialnet.unirioja.es/servlet/articulo?codigo=2254504

Mangado, X. 2005, La caracterización y el aprovisionamiento de los recursos abióticos en al Prehistoria de Cataluña: Las materias primas silíceas del Paleolítico Superior final y el Epipaleolítico. BAR International Series Vol. 1420. British Archaeological Reports, Oxford, 205 p. (in Spanish) ("The characterization and abiotic ressources during the Prehistory of Catalonia: siliceous raw materials from the Upper Final Palaeolithic and Epipalaeolithic”)

Morgado, A. \& Roncal, E. 2009, Los últimos talladores del sílex. Estudio históricoarqueológico sobre la explotación del sílex en las sierras de Loja y la producción militar de piedras de chispa en el reino de Granada durante los siglos XVIII y XIX. Fundación Ibn al-Jatib, Ayuntamiento de Loja, Diputación de Granada, Loja, 342 p. (in Spanish) ("The last flint carvers. Historical-archaeological study of the flint exploitation workshops of sierra de Loja and the military production of spark stones in the Granada kingdom during the 18th and 19th centuries”)

Pérez, F., Fanlo, J. \& Picazo, J.V. 2010, El poblamiento antiguo en el valle del río Huerva. Resultados de las campañas de prospección de 2007-2009. Saldvie, 10: 285-315. (in Spanish) ("Ancient settlement in the river Huerva valley. Results of the 2007-2009 fieldwork surveys”) URL: https://dialnet.unirioja.es/servlet/articulo?codigo=3897809

Roncal, M.E., Martínez, G. \& Morgado, A. 1996, Las piedras de chispa: una producción lítica olvidada en España. Munibe, 48: 105-123. (in Spanish) ("Spark stones: a forgotten lithic production in Spain")

URL: http://www.aranzadi.eus/fileadmin/docs/Munibe/1996105123AA.pdf

Strauss, A., Oliveira, R.E., Villagran, X.S., Bernardo, D.V., Salazar-García, D.C., Bissaro, M.C., Pugliese, F., Hermenegildo, T., Santos, R., Barioni, A., de Oliveira, E.C., Moreno de Sousa, J.C., Jaouen, K., Ernani, M., Hubbe, M., Inglez, M., Gratão, M., Rockwell, H., Machado, M., de Souza, G., Chemale, F., Kawashita, K., O'Connell, T.C., Israde, I., Feathers, J., Campi, C., Richards, M., Wahl, J., Kipnis, R., Araujo, A.G.M. \& Neves, W. 2016, Early Holocene ritual complexity in South America: the archaeological record of Lapa do Santo (east-central Brazil). Antiquity, 90(354): 1454-1473. doi:10.15184/aqy.2016.220

Tarriño, A. 2006, El sílex en la Cuenca Vasco-Cantábrica y Pirineo navarro: caracterización y su aprovechamiento en la Prehistoria. Monografía del Museo Nacional y Centro de Investigaciones de Altamira Vol. 21. Ministerio de Cultura, Madrid, 263 p. (in Spanish) ("Flint in the Vasco-Cantabrian Basin and Pyrenees of Navarra: characterization and procurement during Prehistory”)

Terradas, X. 1996, La gestió dels recursos minerals entre les comunitats caçadoresrecol-lectores: vers una representació de les estratègies de proveïment de matèries primeres. Unpublished Ph.D. thesis at Universitat Autònoma de Barcelona, Barcelona, 269 p. (in Catalan) ("Mineral sources procurement in hunter-gatherer communities: thowards a representation of raw material procurement strategies") 